\title{
PENGELOLAAN ARSIP KONVENSIONAI DI PERPUSTAKAAN SMA YPI TUNAS BANGSA PALEMBANG
}

\author{
Abdurrahman Yasir \\ abdurrahman12@gmail.com \\ Amy Triyani \\ amytriyani@gmail.com \\ Choirunnisyah Alvrida \\ choirunnisyahalda@gmail.com \\ Ferda Juniarisma \\ ferdajunia@gmail.com \\ Gita Fitri \\ gitafitri@gmail.com \\ Rozali Kholid \\ rozalikholid@gmail.com
}

Jurusan Ilmu Perpustakaan, Fakultas Adab dan Humaniora, UIN Raden Fatah Palembang

\section{Abstrak}

\section{PENDAHULUAN}

\section{A. Latar belakang}

Suatu sekolah selalu membutuhkan bantuan data dan informasi untuk menyelesaikan pengelolaan dan mengefektifkan berbagai macam arsip manual untuk mencapai tujuan-tujuan dengan baik pula. Maka dari itu dalam sekolah pun arsip sangat memerlukan suatu bagian penting untuk mengelola arsip tersebut. Apabila arsip yang dimiliki oleh sebuah sekolah kurang baik pengelolaannya, akan mengakibatkan sulitnya menemukan informasi yang telah disimpan dan pada akhirnya dapat menghambat tahapan proses pekerjaan selanjutnya. Mengingat kembali bahwa peran arsip sangatlah penting, maka sebaiknya arsip dikelola menggunakan sistem pengelolaan arsip yang baik dan benar.

\begin{abstract}
Sistem penyimpanan Arsip di SMA YPI Tunas Bangsa Palembang ini merapkan sistem sentralisasi, sesuai dengan namanya kata "sentral", Jikatakan bahwa arsip di SMA YPI Tunas konvensionalnya terpusat, yakni di Perpustakaan Sekolah, berdasarkan hasil dari observasi yang telah dilakukan secara bersama-sama melalui
\end{abstract} Kata kunci: Arsip konvensional, temu kembali, penyimpanan, penyusutan. 
Sejalan dengan pernyataan demikian, itulah alasan mengapa team 7 (tujuh) tersebut melakukan observasi di SMA YPI Tunas Bangsa Palembang. Karena dilihat dari sistem pengelolaannya yang masih kurang terorganisir lantaran sumber daya manusia dalam mengelola arsip-arsipnya adalah tenaga pengajar, bukanlah dari tenaga profesional bidang kearsipan atau yang biasa disebut arsiparis.

Dalam sebuah sekolah, arsip diperlukan untuk memberi pelayanan kepada pihak lain dan untuk keperluan informasi intern dalam sekolah itu sendiri. Oleh sebab itu, arsip sangat berpengaruh pada seluruh kegiatan yang berhubungan dengan pengelolaan disegala bidang yang terdapat dalam sebuah sekolah. Arsip juga merupakan pusat ingatan dari sebuah sekolah, dengan arsip dapat diketahui bermacam-macam informasi yang sudah dimiliki sekolah tersebut sehingga dapat ditentukan sasaran yang akan dicapai dengan menggunakan potensi yang ada secara maksimal. Informasi yang diperoleh melalui arsip juga dapat menghindarkan salah dalam berkomunikasi.

\section{B. Rumusan masalah}

Beberapa permasalahan yang penulis dapatkan dari latar belakang sebelumnya adalah sebagai berikut:

1. Bagaimana cara pengelolaan arsip di SMA YPI Tunas Bangsa Palembang?

2. Bagaimana sistem temu kembali arsip konvensional?

3. Bagaimana dengan pemusnahan arsip yang tidak digunakan lagi?

\section{Tujuan}

1. Untuk mengetahui pengelolaan arsip di SMA YPI Tunas Bangsa Palembang.

2. Untuk mengetahui penyusutan arsip yang tidak digunakan kembali.

3. Untuk mengetahui sistem temu kembali arsip konvensional.

\section{PEMBAHASAN}

Menurut Lembaga Administrasi Negara (LAN), arsip adalah segala kertas, berkas, naskah, foto, film, mikro film, rekaman suara, gambar peta, bagan atau dokumen lain dalam segala macam bentuk dan sifatnya atau salinan serta dengan segala cara penciptaanya, dan yang dihasilkan atau diterima oleh suatu badan, sebagai bukti dari tujuan organisasi, fungsi-fungsi kebijakan. Kebijakan, keputusan-keputusan, prosedur-prosedur, pekerjaanpekerjaan atau kegiatan-kegiatan lain pemerintah atau karena pentingnya informasi yang terkandung di dalamnya

Arsip adalah catatan rekaman kegiatan atau sumber informasi dengan berbagai macam bentuk yang dibuat oleh lembaga, organisasi maupun perseorangan dalam rangka pelaksanaan kegiatan. Arsip dapat berupa surat, warkat, akta, piagam, buku, dan sebagainya, yang dapat dijadikan bukti sahih untuk suatu tindakan dan keputusan. Dengan adanya perkembangan teknologi, arsip dapat berbentuk audio, video dan digital. Menurut Read \& Ginn 
(2011:5) dalam bukunya berjudul Record Management mengutip definisi arsip dari ARMA Internasional dan International Organization for Standardization (ISO) 15489. Menurut ARMA Internasional arsip adalah informasi yang disimpan dalam bentuk dan karakteristik apapun, dibuat atau diterima oleh organisasi sebagai bukti kegiatan serta memiliki nilai dalam jangka waktu tertentu. Sedangkan International Organization for Standardization (ISO) 15489 mendefinisikan arsip sebagai informasi yang dibuat, diterima, dan dipelihara sebagai bukti dan informasi bagi organisasi atau individu untuk kepentingan hukum maupun bisnis. Sama halnya seperti pengertian dalam pengelolan arsip konvensional di SMA YPI Tunas Bangsa Palembang. Pada dasarnya konsep arsip tidak dapat dipisahkan dengan berbagai macam informasi, karena arsip merupakan informasi yang diterima, dan disimpan dalam berbagai bentuk lalu disusun secara rapi di berbagai rak, baik oleh perorangan maupun perkelompok. Suatu arsip harus dikelola dengan baik karena nilai dan tingkat kepentingannya berbeda-beda, baik untuk kepentingan yuridis, bukti historis, maupun kepentingan transaksi bisnis.

\section{A. Pengorganisasian Arsip di SMA YPI Tunas Bangsa Palembang}

Pengorganisasian arsip menurut Agus Sugiarto (2005:21) membicarkan siapa yang melakukan pengelolaan arsip dalam suatu organisasi. Agar adanya kejelasan dalam hal pembagian tugas dan siapa yang menjadi tanggung jawab. Ada beberapa arsip kantor yang sudah dikenal yaitu

\section{Sentralisasi}

Yaitu system pengelolaan arsip yang dilakukan secara terpusat dalam suatu organisasi atau dengan kata lain menyimpan arsip yang dipusatkan disuatu unit kerja khusus yang lazim disebut sentral lazim. Sistem ini lebih mengungkapkan untuk digunakan alat organisasi atau perusahaan yang kecil.

2. Desentralisasi

Yaitu pengelolaan arsip yang dilakukan pada setiap unit kerja dalam suatu organisasi atau setiap unit mengelola arsipnya masing-masing. Sistem ini lebih mengutungkan untuk digunakan oleh organisasi atau perusahaan yang lebih besar.

3. Kombinasi sentralisasi dan desentralisasi

Yaitu gabungan dari system sentralisasi dan desentralisasi untuk mengatasi kelemahan dari dua cara pengelolaan arsip. Adapun kerugian pada system sentralisasi dan desentralisasi yaitu

a. Kerugian sistem sentralisasi

i. Tidak semua jenis arsip disimpan dengan satu system penyimpanan yang seragam.

ii. Unit kerja yang memerlukan arsip akan memakan waktu lebih lama untuk memperoleh arsip yang diperlukan

b. Kerugian system desentralisasi 
i. Penyimpanan arsip tersebar diberbagai lokasi dan dapat menimbulkan duplikasi arsip yang disimpan

ii. Kantor harus menyediakan peralatan dan perlengkapan arsip disetiap unit kerja

iii. Penataran dan pelatihan kearsipan perlu diadakan karena petugas-petugas umumnya rangkap dan tidak mempunyai latar belakang pendidikan kearsipan

iv. Kegiatan pemusnahan arsip harus dilakukan setiap unit kerja dan ini merupakan pemborosan

v. Jadwal retensi arsip ialah daftar yang berisi sekurangkurangnya jangka waktu penyimpanan atau retensi, jenis arsip dan keterangan yang berisi rekomondasi tentang penetapan suatu jenis arsip dimusnahkan dinilai kembali atau dipermanenkan yang dipergunakan sebagai pedoman penyusutan atau penyelamatan arsip.Jadwal retensi arsip merupakan juga alat yang amat penting dalam manajemen kearsipan, karena dapat member sumbangan nyata pada upaya peningkatan efesiensi operasional instansi dan member proteksi terhadap arsip yang karena memuat informasi bernilai guna tinggi agar dapat dilestarikan. Jadwal retensi arsip merupakan pedoman kerja petugas arsip/arsiparis dalam penyusutan arsip-arsip yang secara minimal harus mencakup jenis arsip, jangka simpan dan keterangan arsip akhir. Fungsi dari jadwal retensi arsip ialah sebagai subsistem manajemen

peningkatan efesiensi operasional dan pelestarian bukti pertanggungjawaban nasional. Kemudian penentuan jangka simpan arsip pada prinsipnya mempertimbangkan dua hal yaitu kebutuhan mendukung (business activity) dan memenuhi ketentuan perundang-undangan. Pembuatan jadwal retensi arsip adalah kewajiban dan hak sepenuhnya instansi pencipta arsip. Proses penetapan jadwal retensi arsip ialah produk hukum, untuk menjamin bahwa penyusutan arsip dilakukan sesuai dengan ketentuan hukum yang berlaku.

Sistem penyimpanan arsip di SMA YPI Tunas Bangsa Palembang ini menerapkan sentralisasi, sesuai dengan namanya kata "sentral", yaitu titik paling terpusat. Dapat dikatakan bahwa arsip di SMA YPI Tunas Bangsa Palembang ini menggunakan metode pengumpulan suatu arsipnya sangat terpusat di suatu tempat, tepatnya di Perpustakaan Sekolah, ini berdasarkan hasil dari observasi yang telah dilakukan secara bersama-sama melalui metode wawancara langsung kepada pihak Kepala Perpustakaan tersebut. Setelah team 7 membuktikan dengan melakukan observasi tersebut ,maka 
arsip di sekolah SMA YPI Tunas Bangsa Palembang seluruhnya masih berbentuk konvensional (manual). Arsip-arsip konvensional tersebut dapat berupa soal-soal ujian semesteran dari seluruh tingkat, daftar pengadaan yang pernah dilaksanakan, daftar inventaris, Surat Keterangan Izin Bangunan Sekolah, maupun surat-surat penting lainnya misal pengangkatan Kepala Sekolah, surat pemberhentian para Guru, dan seluruh arsip-arsip administrasi sekolah yang bersangkutan yang diletakkan pada rak dan filling cabinet. Khusus rak, arsip-arsipnya disusun layaknya buku di perpustakaan pada umumnya.

Dengan begitu banyaknya jenis arsip yang tersimpan di perpustakaan, SMA YPI Tunas Bangsa Palembang ini sangat disayangkan karena tidak melakukan alih media ke eletronik. Dengan mengelektronikkan suatu arsip, maka akan mempermudah melakukan pengelolaan, temu kembali, bahkan membantu meringankan kerja dari tenaga pengolahnya. Pasalnya, jika terjadi kehilangan, dengan elektronik tenaga pengelolanya hanya perlu mengacu pada data-data yang tersimpan secara elektronik kemudian mem-back up-nya dengan mudah. Dan yang terpenting, menghemat tempat, karena ada baiknya perpustakaan hanya menjadi perpustakaan, tidak perlu dicampurtangani oleh arsip dan kegiatannya. Sepenuhnya, dapat dipahami, bahwasanya selain faktor mahalnya biaya untuk mengalihmediakan arsip, kompetensi dan kreativitas sumber daya pengelola arsipnya jugalah yang dapat jadi penentu baik atau tidaknya pengorganisasian arsipnya.

\section{B. Sistem Temu Kembali Arsip Konvensional di SMA YPI Tunas Bangsa Palembang}

Arsip-arsip yang disimpan pada tempat penyimpanan arsip mempunyai tujuan agar mudah ditemukan kembali secara cepat dan tepat untuk kelancaran sebuah kegiatan dan penggunaan informasi vital yang sedang dibutuhkan. Berdasarkan observasi dan wawancara yang team 7 lakukan di Perpustakaan SMA YPI Tunas Bangsa Palembang, mereka menggunakan buku daftar atau agenda tentang arsip apa yang disimpan di perpustakaannya. Arsip-arsip tersebut dikelompokkan berdasarkan jenis di dalam map, kemudian di susun pada rak-rak selayaknya buku. Tidak hanya di rak, arsip-arsip itu juga di simpan di dalam filling cabinet.

Cara penelusurannya adalah dengan melihat langsung pada daftar agenda atau langsung pada rak-rak yang telah diberi tempelan di pinggiran sekat rak sebagai subjek pengenal arsip tersebut itu apa. Penandanya juga ada di bagian depan map penyimpan arsip.

Sebenarnya, teknik simpan dan temu kembali arsip di Perpustakaan SMA YPI Tunas Bangsa Palembang ini sangat tidak efektif dan efisien, sebab menyulitkan temu kembali dan juga memerlukan waktu yang lama untuk menelusur. Belum lagi, di sana juga menyimpan arsip-arsip penting lembaga induknya (sekolah). Jadi, menurut penulis, ada baiknya menciptakan cara atau memiliki alat bantu alternatif yang mempermudah untuk proses temu kembali. Atau cara terbaik adalah, menyediakan ruangan khusus guna menampung seluruh arsip sekolah, supaya tidak tercampur dengan kegiatan 
kepepustakaan. Sebab, jika sewaktu-waktu arsip itu sangat dibutuhkan, pihak pengelolahnya tidak perlu sibuk mencari satu per satu dari sekian banyak arsip hanyak untuk menemukan sebuah arsip.

\section{Pemusnahan Arsip di SMA YPI Tunas Bangsa Palembang}

Secara umum Pemusnahan Arsip adalah aktivitas menghancurkan arsip yang sudah telah habis guna. Pengertian Pemusnahan Arsip menurut Peraturan Pemerintah Nomor 34 Tahun 1979 yaitu tindakan atau kegiatan menghancurkan secara fisik arsip yang sudah berakhir fungsinya serta tidak memiliki nilai guna secara total dengan cara membakar habis, dicacah atau dengan cara lain sehingga tidak dapat lagi dikenal baik isi atau bentuknya.

Sama halnya dengan pemusnahan arsip, di SMA YPI Tunas Bangsa Palembang biasanya seperti arsip berguna (persentase nilai 10-49), pemusnahan dilakukan setelah arsip disimpan dengan status aktif selama 2 (dua) tahun dan inaktif selama 10 (sepuluh) tahun. Contohnya Arsip Laporan Tahunan, Arsip Neraca, dll, lalu arsip tidak berguna (persentase nilai 0-9), arsip golongan ini dapat langsung dimusnahkan atau disimpan dalam pusat arsip paling lama 3 (tiga) bulan. Contohnya, arsip undangan, arsip pengumuman, sama seperti arsip halnya dengan arsip tidak berguna, arsip pengumuman termasuk arsip tidak berguna maupun tidak penting dikarenakan arsip tersebut hanya bersifat sementara tidak untuk bersifat permanen, kemudian arsip undangan, seperti arsip undangan untuk mengikuti lomba dari instansi lain sehingga kedua arsip tersebut tidak untuk di simpan sebagai bukti bahwa untuk sistem temu kembalinya informasi, lalu pemusnahan arsip yang tidak berguna dapat dibakar di belakang sekolah dengan cara mengumpulkan lalu membedakan arsip yang berguna dan arsip yang tidak berguna.

\section{KESIMPULAN}

Berikut adalah kesimpulan dari observasi yang telah kami lakukan di SMA YPI Tunas Bangsa Palembang:

1. Arsip di SMA YPI Tunas Bangsa Palembang disimpan dengan metode sentralisasi, yakni disimpan secara terpusat di dalam perpustakaan. Pengelolaannya yakni setelah arsip itu diciptakan dan sudah dipakai, arsip tersebut dimasukkan ke dalam map lalu disimpan di dalam filling cabinet, sebagian juga ada disusunkan pada rak selayaknya buku bacaan. Di depan map maupun di sekat-sekat rak, terdapat tanda atau subjek pengenal, jenis apa arsip tersebut.

2. Sistem temu kembali arsip di SMA YPI Tunas Bangsa Palembang, yakni dengan metode pencarian satu per satu. Tanda pengenalnya hanyalah subjek di depan map maupun di sekat-sekat rak, dan juga buku daftar agenda, arsip apa yang telah di simpan.

3. Pemusnahan arsip di SMA YPI Tunas Bangsa ialah dengan cara dibakar, setelah melalui proses pemilahan arsip mana yang bernilai guna atau yang tidak, dan persetujuan dari Kepala Sekolah. 


\section{DAFTAR PUSTAKA}

Read, J. \& Ginn, M. L. (2011). Record management (9th ed.). Mason, Ohio: Thomson South-Western.

Robbins, S. P, \& Coulter, M. (2009). Management (10th ed.). Upper Saddle River, New Jersey: Pearson Education Inc.

Sulistyo Basuki (2008). Manajemen Arsip Dinamis: pengantar memahami dan mengelola informasi dan dokumen, Jakarta: Gramedia

Syihabuddin Qalyubu dkk (2003) Dasar-Dasar Ilmu Perpustakaan Dan Informasi Yogyakarta : IAIN Sunan Kalijaga

Martono, Boedi. 1990. Sistem Kearsipan Praktis: Penyusutan dan Pemeliharaan arsip. Jakarta: Pustaka Sinar Harapan

Sedarmayanti, 1992. Tata Kearsipan Dengan Memanfaatkan Teknologi Modern. Bandung: Ilham Jaya Offset

Monika Nur Lastiani (2008) Manajemen Arsip Elektronik

Muhammad Rasyid Budiman (2009). Dasar Pengelolaan Arsip Elektronik Yogyakarta: Badan Perpustakaan Dan Arsip Daerah. 